\section{Veistoksesta versioon}

Veijo Pulkkinen: Epäilyksen estetiikka. Tekstuaalinen variaatio ja kirjallisen teoksen identiteetti. Oulu: Oulun yliopisto, 2010. $242 \mathrm{~s}$.

Englannissa ja Amerikassa teoreettinen ja tulkinnallinen kirjallisuudentutkimus erotetaan usein vähemmän tärkeinä pidetyistä lähdekriittisistä aputieteistään, kuten bibliografiasta, kodikologiasta, paleografiasta, diplomatiikasta, kriittisestä editoinnista ja stemmatologiasta. Näitä aputieteitä on kutsuttu kootusti nimellä "scholarship", tai tekstuaalitieteet, kuten suomalaisittain on sovittu puhuttavan. Viime vuosikymmeninä nämä aputieteet ovat kuitenkin saaneet osakseen laajempaa huomiota. Syitä on monia, kuten arkistojen digitoinnin herättämät kysymykset kirjallisten teosten luonteesta, tekijänoikeuksista, kustantamisen tulevaisuudesta ja niin edelleen. Mielenkiintoisin lienee kuitenkin tekstuaaliteoreetikkojen laajalti esittämä haaste, jonka mukaan kirjallisuudentutkijoiden olisi syytä kiinnittää huomiota tulkinnallisen variaation lisäksi myös tekstuaalisen variaation ongelmiin. Tulkintaperinteemme mukaanhan tekstit eivät ole merkityksiltään vakaita, vaan historiallisesti, kulttuurisesti ja subjektiivisesti muuntuvaisia - mutta tutkijat useimmiten unohtavat, paradoksaalista kyllä, tekstien materiaalisen muuntuvaisuuden.

Tekstuaalitieteiden perustana puolestaan on ajatus, jonka mukaan kirjalliset teokset ovat lukuisten skriptiaktien tuotteita, kuten Peter Shillingsburg on todennut. Kirjallista teosta ei pitäisi pelkistää satunnaisen painoksen satunnaiseen kappaleeseen painettuun tekstiin. Todellisuudessa teos koostuu lukuisista versioista - kuten käsikirjoitusversioista ja oikovedoksista, korjatuista tai muuten toisistaan poikkeavista painoksista - ja kirjailijan, toimittajien ja muiden niihin tekemistä muutoksista. Teoksen tekstiin vaikuttavat kopistien ja latojien tekemät virheet eri painoksissa ja eri julkaisuvaiheissa sekä monet muut tekstuaalisen transmission prosessit (kuten 1800-luvun romaanien julkaisu ensin jatkosarjoina lehdissä, sitten kirjoina). Näiden tutkiminen on tekstuaalitieteiden alaa.

Veijo Pulkkisen väitöskirja Epäilyksen estetiikka. Tekstuaalinen variaatio ja kirjallisen teoksen identiteetti on ensimmäinen suomalainen näitä kysymyksiä käsittelevä tutkimus. Se on ansiokas johdatus alansa aiheisiin ja pioneerityö etenkin luodessaan alan suomenkielistä terminologiaa.

Kolmiosaisessa tutkimuksessaan Pulkkinen lähtee kirjallisuudentutkimuksen ja tekstuaalitieteiden institutionaalisesta erottelusta. Hän toteaa pyrkivänsä selittämään, miten ja miksi erottelu syntyi, sekä tarjoamaan poikkitieteellisen analyysin, jonka avulla tästä kirjallisuustieteellisestä apartheidista voitaisiin päästä eroon. Rotuerottelu on uuden ajan ilmiö, ja Pulkkinen näkee sen syyksi juuri edellä kuvatun monoliittisen teoskäsityksen. Tämän sukujuuria hän jäljittää ensimmäisessä pääluvussaan antiikista asti painotaidon ja modernin tekijäkäsityksen syntymään ja siitä nykypäivän hypertekstiteoriaan. Keskeiseksi Pulkkinen näkee anglo- 
amerikkalaisten yliopistojen institutionaalisen muutoksen 1900-luvun alussa. Tällöin kirjallisuudentutkimus erotti itsensä tekstuaalitieteistä suorittamalla "tieteidenvälisen työnjaon" muun muassa uuskritiikin ja analyyttisen estetiikan tarjoamien teoreettisten välineiden avulla: aito tutkimus keskittyköön historiattomaan tekstiin ja sen tulkintaan, ja tekstuaalitieteet käsitelkööt teoksia mykkinä artefakteina.

Kahdessa muussa pääluvussa Pulkkinen kritisoi tätä teoskäsitystä analyyttisessä kirjallisuudenfilosofiassa ja soveltaa sen tilalle kehittämäänsä epäilyksen estetiikkaa ("jokainen teksti on mahdollisesti virheellinen tai ainoastaan yksi versio teoksesta, jolla voi olla useita erilaisia versioita"[21]) Aaro Hellaakosken runojen analyysissä. Analyyttisen kirjallisuudenfilosofian esittely on pätevää. Hellaakosken runojen analyysistä minulla ei ole kriittistä sanottavaa, ja nautin kovasti Pulkkisen tekstikriittisestä analyysista, joka tarkastelee runojen vaihtoehtoisia versioita.

Läpi Pulkkisen käsittelyn kulkee hänen vakaa uskonsa siihen, että juuri uuskritiikkiä ja analyyttistä estetiikkaa on edelleen, jälkistrukturalismin jälkeenkin, pidettävä monoliittisen teoskäsityksen syntipukkina. Hän kyllä tunnustaa, että "kirjallisen teoksen autonomisuus ja historiallisuus on usein kyseenalaistettu”, mutta väittää, että näin on tehty vain "teoksen merkityksen muodostumisen tasolla”. Siksi uuskritiikin ja analyyttisen estetiikan perintö vaikuttaa yhä, ja "pitää yllä sokeaa luottamusta tekstuaaliseen py- syvyyteen”. (42.)

Tässä kohtaa Pulkkisen tutkimuksen juoni alkaa ontua: tutkijan mukaan ratkaisua tilanteeseen on etsittävä analyyttisen kirjallisuudenfilosofian traditiosta, joka on ylläpitänyt kirjallisuudentutkimuksen ja tekstikritiikin välistä erottelua. Ratkaisu tuntuu oudolta. Ensinnäkin analyyttinen kirjallisuudenfilosofia on paitsi Suomessa, myös kansainvälisesti varsin marginaalinen ala. Toiseksi, olisi ollut paljon mielenkiintoisempaa jäljittää monoliittista teoskäsitystä esimerkiksi jälkistrukturalismin ja kulttuurintutkimuksen valtavirrassa. Nyt Pulkkinen käsittelee näiden taustalla olevia teorioita vain ohimennen hypertekstien teoriaa käsitellessään. Tällöinkin hän väittää, että "Barthesin tekstin, Derridan arkkitekstin tai Deleuzen ja Guattarin rihmaston” kaltaisilla käsitteillä pyritään vain "kuvaamaan niitä abstrakteja merkityksen muodostumisen prosesseja, jotka vaikuttavat aistein havaittavien tekstien ja muiden merkkijärjestelmien pinnan alla” (73).

Pinnanalisuuden metafora on hieman köykäinen. Jälkistrukturalismiin (sikäli kuin se on olemassa piirteikkäänä oliona) eivät kuulu tällaiset kognitiiviset metaforat, vaan juuri niiden pystyttämän ajattelun logiikan kyseenalaistaminen. Huomautan asiasta, koska tekemänsä rajauksen takia Pulkkiselta jää käsittelemättä yksi oleellinen syy angloamerikkalaisen kirjallisuudentutkimuksen rotuerotteluun: mannermaisen filosofian ja kriittisen teorian vaikutus.

Suuri osa amerikkalaista kirjallisuudentutkimusta lähestyy kirjallisuut- 
ta poliittisen ja filosofisen analyysin välineenä: tutkimuksen kohteena on ideologinen ajattelu, joka teoksissa ilmenee. Tekstuaalitieteiden heikon aseman taustalla ei siis ole ainakaan Amerikassa ollut (pelkästään) vääränlainen teoskäsitys, vaan se tosiasia, että hyperpolitisoituneessa ilmapiirissä on ollut poliittisesti epäkorrektia kiinnittää huomiota scholarship-tyyppisiin aiheisiin, jotka kiinnittävät huomion "epäolennaiseen" rodun, seksuaalisuuden, sukupuolen tai muiden tärkeämpien aiheiden sijaan. Tai näin ainakin oli, ennen kuin Jerome J. McGannin kaltaiset vasemmistolaiset tekstuaalitieteilijät huomauttivat 80-luvulla, että ideologiakriittisenkin analyysin on käsiteltävä niitä teoksen versioita, joita tiettynä historian hetkenä on luettu, eikä (kuten usein tapahtuu) myöhemmin toimitettuja kriittisiä editioita, joiden teksti saattaa poiketa alkuperäisestä huomattavasti.

Esittämästäni kritiikistä huolimatta on kulttuuriteko, että Pulkkinen kääntää tärkeää keskustelua ja käsitteistöä selvälle suomen kielelle. Hänen esittelemänsä epäilyksen estetiikan toivoisi yleistyvän kotimaisessa kirjallisuudentutkimuksessa. Olisi myös kiinnostavaa, jos joku Pulkkisen innoittamana kysyisi, miksi Suomessa on vasta nyt, 2000-luvulla, herätty toimittamaan kriittisiä editioita kirjallisesta perinnöstämme - tai ylipäätään pohtimaan tekstuaalitieteiden paikkaa kirjallisuudentutkimuksen kentällä.

\section{Teemu Manninen}

\section{Sotakirjat sensuurin kourissa}

Helena Pilke: Etulinjan kynämiehet. Suomalaisen sotakirjallisunden kustantaminen ja ennakkosensuuri kirjojen julkaisutoiminnan sääntelijänä 1939-1944. Bibliotheca Historica 123. Helsinki: SKS, 2009. 339 s.

Sotakirjallisuus on nähty suomalaiselle kustannustoiminnalle luonteenomaisena lajina, kansallisen identiteetin kannattajana. Siksi se on pitänyt pitkään yllä suosiotaan muuttuneista oloista huolimatta. Viime sodista - talvi- ja jatkosodasta - on seitsemän vuosikymmenen aikana julkaistu niin faktaa kuin fiktiotakin tuhansin tittelein, eikä mikään viittaa siihen, että sotakirjat katoaisivat kirjamarkkinoilta. Luonnollista on, että autenttisuuden aste sodankuvauksessa on vähentynyt ja suhde taisteluihin muuttunut etäisemmäksi, vähemmän intohimoja herättävään suuntaan.

Sodasta voidaan tutkimuksenkin puolella kirjoittaa entistä paremmin metodisin varustein sikäli kuin aineistot antavat myöten. Paljon sodanaikaisesta lähdemateriaalista on kuitenkin hävinnyt tai suoranaisesti tuhottu. Tämä käytännön ongelma näkyy myös Helena Pilkkeen väitöskirjassa Etulinjan kynämiehet, joka on tarkastettu Turun yliopistossa kulttuurihistorian oppiaineessa. Tutkiessaan sodanaikaista kustannustoimintaa ja erityisesti sensuurin vaikutusta sotakirjojen julkaisemiseen Pilke on ymmärrettävästi törmännyt vaillinaisiin aineistoihin, 
keskeisten arkistosarjojen fragmentaarisuuteen ja kirjeenvaihdon aukkoihin. Sensorien, kuten esimerkiksi Valtion tiedotuslaitoksen päällikkönä jatkosodan aikana toimineen Kustaa Vilkunan, muistelmat vaikenevat aroista asioista.

Vaikeuksista huolimatta Pilke on rakentanut vuosien 1939-1944 tuottaman sotakirjallisuuden syntyoloista ja julkaisemisen rajoituksista selkeän kokonaiskuvan, joka samalla muodostuu yhtenäiseksi tarinaksi. Kuten draaman kaareen, siihen sisältyy jännitteitä, huippuja laskukohtia. Välivaiheessa ja finaalissa suurvaltaintressien puututtua peliin ulkoministeri Molotovin hahmossa talvisodan jälkeen ja jatkosodan päätyttyä vahvemman osapuolen ehdoilla solmittuun välirauhaan - sotakirjallisuus näytti saaneen kuoliniskun. Mutta sekä ulkonaisista kolhaisuista että arvostuksen puutteesta piittaamatta laji on aina selvinnyt lamasta ja jatkanut elämäänsä uuden vuosituhannen puolelle saakka.

Kirjallisuudentutkimuksen piirissä sodankuvauksista on tehty aikojen kuluessa erinäisiä monografioita, joita Pilkkeen kulttuurihistoriallinen ote sopivasti rikastaa ja täydentää. Tutkimusmetodia väitöskirjassa voi väljästi luonnehtia kirjallisuussosiologiseksi tai kulttuurintutkimukselliseksi. Pilke selvittää perusteellisesti niitä institutionaalisia mekanismeja, joiden kautta sotakirjallisuus 1940-luvulla haki muotoa ja jotka säätelivät sen ideologisia sisältöjä. Tutkija korostaa työnsä kvalitatiivisia lähtökohtia, vaikka kokoaa myös kovaa faktaa julkaisuista ja sensuurin toiminnasta. Pilke on perehtynyt omakohtaisesti kustannustoimintaan WSOY:n kirjakerhon palveluksessa. Kotikenttäetu on selvästi tuonut tutkimukseen lisäarvoa: väitöskirjan tekijä tuntee kustannustalojen käytänteitä ja pystyy siten hyödyntämään niiden arkistoja täysimääräisesti.

Tutkimus osoittaa, että suomalainen kustannusjärjestelmä ja sitä säätelevä ennakkosensuuri joutuivat talvisodassa ja jatkosodan alussa kohtaamaan käsikirjoitusten tulvan valmistautumattomina ja sen takia improvisoimaan toimintatapojaan. Nopeat söivät hitaita: niinpä pienempänä kustantamona Arvi A. Karisto Oy pystyi talvisodan jälkeen valtaamaan markkinoita, kun suuret - WSOY ja Otava - vasta etsivät strategioitaan.

Merkittävässä roolissa ensimmäisten sotakirjojen impressaarina toimi dynaaminen kustannusjohtaja - kuten Kariston legendaarinen V. Hämeen-Anttila, joka ryhtyi itse leipomaan tarjotuista teksteistä julkaisukelpoisia teoksia. Kirjailijoiden, kustantajien ja sensorien kirjeenvaihdosta Pilke on saanut tutkimukseensa runsaasti värikkäitä sitaatteja, jotka kertovat ajan hengestä ja poliittisista käänteistä sotakirjojen taustalla. Kirjailijoiden, kustantajien ja sensuurin suhdetta vuosina 1939-1944 Pilke luonnehtii "eräänlaiseksi pakon edessä solmituksi aseveljeydeksi, jossa joukkoja johti sensuuri”.

Tutkimuksellisten ansioiden ohella Etulinjan kynämiehet käy mallikelpoisesta esimerkistä siitä, miten tieteellinen esitys ottaa lukijan huomioon. Pilke kirjoittaa 
tyylikkäästi ja tarvittaessa tiivistää iskevin virkkein tutkimuksensa tuloksia. Hänen mukaansa sota-aika teki suomalaisista lukijakansaa, ja samalla kirjojen tehtävät moninaistuivat: "Kirja kuului sodan aikana kotiin ja korsuun. Se antoi lukijalle pakomahdollisuuden arjesta, tarjosi tietoa oman maan ja maailman tilanteesta, opetti hyödyntämään vadelmanlehdet ja vaarin vanhan takin. Kirja toi lohtua sankarivainajan omaisten suruun, esitteli nuorille neuvokkaita ja sankarillisia idoleja ja muistutti rintamamiehen mieleen oman yksikön tai rintamaosan tapahtumat, joista ei juoksuhaudassa saanut kokonaiskäsitystä.”

Tutkimuksen kulttuurihistoriallisesta lähtökohdasta johtunee, että sotakirjallisuus on väitöskirjassa määritelty kovin väljästi: mukaan tarkasteluun on otettu kaikenlaisia painotuotteita kartoista erilaisiin kuvateoksiin saakka. Käsitteen määrittelyn väljyys tuottaa sinänsä kiinnostavaa detaljitietoa, joka ehkä sensuurin toimintatapojen kuvaajana puolustaa paikkaansa. Sotakirjallisuuden laadullisen analyysin kannalta rajaukset vievät kuitenkin välillä kyseenalaisille sivupoluille. Löysyyttä laajassa työssä löytyy jonkin verran senkin takia, että muutamat havainnot on kirjattu melkein sanasta sanaan pariin kertaan.

Analysoidessaan sotakirjojen institutionaalisia ehtoja Helena Pilkkeen väitöskirja avaa arvokkaita näkökulmia myös kirjallisuudentutkijan käyttöön. Tutkimuksen tuloksilla on pysyvää merkitystä, ja ne inspiroivat edelleen jatkotutkimuk- siin, joihin Pilkekin viittaa. Esimerkiksi kotirintamakirjallisuus, nuortenkirjallisuus ja naistenviihde sota-ajalta vaatisivat omat perusteelliset kartoituksensa.

\section{Juhani Niemi}

\section{Kirjan matka äärestä viereen}

Kai Häggman: Paras tawara maailmassa. Suomalainen kustannustoiminta 1800 luvulta 2000-luvulle. Helsinki: Otava, 2008. $622 \mathrm{~s}$.

Jyrki Hakapää: Kirjan tie lukijalle. Kirjakauppojen vakiintuminen Suomessa 1740 1860. Suomalaisen Kirjallisuuden Seuran Toimituksia 1166. Helsinki: SKS, 2008. $466 \mathrm{s.}$

Pari vuotta sitten ilmestyneet Jyrki Hakapään väitöskirja Kirjan tie lukijalle ja Kai Häggmanin Suomen kustannusyhdistyksen 150-juhlavuotishistoriikki Paras tawara maailmassa kiinnittyvät kirjahistorian tutkimustraditioon, jota on viime aikoina Suomessa systemaattisesti kehitetty. Yhtälailla ne molemmat osaltaan sivuavat suomalaisen kirjallisuusinstituution tai -järjestelmän sosiologista tutkimusperinnettä. Molemmat tutkijat ovat tieteelliseltä taustaltaan historioitsijoita, mikä näkyy heidän teostensa lähestymis- ja esitystavoissa, ennen muuta käsitteiden muodostuksessa ja käytössä. Yhdessä teokset muodostavat varsin eheän kronologisen kuvauksen suomalaisen 
kirjan kulttuurisesta, taloudellisesta ja sosiaalisesta merkityksestä 1700-luvun lopulta 2000-luvulle. Hakapään käsittelemä ajallinen jakso on 1700-luvun lopulta 1850-luvun suomalaisen kirja-alan kriisiin. Häggmanin teos puolestaan alkaa "kirjallisen takatalven" nujertamiseksi perustetun Suomen kustannusyhdistyksen syntyideasta, vuodesta 1857 , ja ulottuu näihin päiviin saakka.

Tottahan teosten välillä on suuriakin eroja, jo niiden erilaisen luonteen takia. Hakapään tutkimus on väitöskirja, joka noudattaa tunnontarkasti korkeimmalta akateemiselta opinnäytteeltä edellytettäviä argumentaation, dokumentoinnin ja esittämisen perinteitä. Häggmanin historiikki on puolestaan eri organisaatioiden ja yritysten historiaa sekä perhehistoriaa tutkineen ammattihistorioitsijan vapaammin kirjoitettua, kuvin höystettyä lähteillä ilottelevaa tekstiä. Hakapään tutkimus painottuu kirjallisuuden levitystoiminnan ja -organisaatioiden, ennen muuta kirjakauppatoiminnan syntyyn ja kehitykseen Suomessa, Häggmanin tutkimuksessa kohteena on puolestaan kirjatuotanto. Mutta niin kuin olettaa sopii, kumpikaan tutkijoista ei malta pysyä pelkän primaarikohteensa piirissä, vaan molemmat avaavat tutkimustaan myös kirjallisuusjärjestelmän muille osa-alueille ja yhteiskuntaan yleensä. Omaa tutkimusasetelmaansa Hakapää perustelee todeten, että "[p]ainotuotteita on pystyttävä tarkastelemaan monien eri toimijoiden ja tehtävien synnyttäminä yhteisöllisinä tuotteina”. Tästä hänen varsinaiseksi tutkimuskohteekseen märittyykin ruot- salaisen kirjallisuussosiologin Johan Svedjedalin käsitteen mukaan "kirjan yhteisö”. Eräänlaiseksi tutkimukselliseksi esikuvakseen Hakapää tunnustaa amerikkalaisen, Ranskan kulttuurihistoriaan keskittyneen Robert Darntonin, joka muun muassa kirjahistorian näkökulmasta on kehittänyt uuden näkökulman Ranskan suureen vallankumoukseen.

"Sven Gabriel Elmgren jäi eläessään aikalaistensa varjoon, eikä häntä myöhemminkään ole juuri muistettu.” Tällä lauseella Häggman aloittaa tutkimuksensa. Se on viittaus siihen, mitä tuleman pitää: Elmgren-aloituksellaan Häggman osoittaa, että vaikka hänen tutkimuksensa kohde on merkittävä suomalainen kulttuurilaitos, ei tutkimuksen tarvitse perustua yksinomaan rakenteellisiin analyyseihin, numeraalisiin esityksiin tai virallisiin asiakirjoihin. Pienestä ja unohdetusta löytyy yhtälailla merkittävää, jopa mielenkiintoisempaa tietoa ja tutkimuksen materiaalia. Tällä tavoin intiimi, kuten vaikkapa Elmgrenin päiväkirjat, rikkoo suurta, jossain määrin jo tunnettua, kertomusta ja tuo tekstiin dynamiikkaa. Paljolti samalla tavoin toimii myös Hakapää, joskin hänen argumentaationsa kulkee yleistävämmällä, alati johtopäätöksiin pyrkivällä ja paikoin abstrahoivalla tasolla. Joka tapauksessa molemmissa tutkimuksissa historian mikro- ja makrotasot risteilevät ja luovat tekstiin tarinallista jännitettä.

Vaikka tutkijoilla molemmilla on oma ajanjaksonsa tarkasteltavanaan, tutkimusten esittämisen logiikka on eri: Hakapään tutkimus rakentuu synkronisesti tutki- 
musteemojen mukaan, Häggman etenee lineaarisemmin. Hakapään tutkimuksen teemoja ovat muun muassa kirjakaupan ominaispiirteet, joihin kuuluvat muun muassa kaupan siirtyminen käsityöläisestä monopoliperiaatteesta universaaliin kauppaan, vaihtokaupasta rahatalouteen, ja virkamiesten valvontavelvoite ja muuntuva asiakaskunta. Toisena suurena teemana Hakapäällä on kirjakaupan toimijat ja toimintaympäristöt (toimipaikat ja liiketilat). Kirjojen tarjonnan tematiikkaa tutkija jäsentää muun muassa myynnin strategioita tarkastelemalla (myyntihakemistot ja tiedonvälitykseen perustuva myynti), selvittämällä kirjojen logistiikkaa ja myynnin rytmiä. Lisäksi Hakapää tarkastelee erikseen kansainvälisen ja kansallisen kirjatuotannon asemaa suomalaisessa kirjakaupassa ja pohtii eri kirjakauppojen menestyksen ja menestymättömyyden syitä: ahtaita markkinoita sekä peruspääoman ja liiketoiminnan laajuuden merkitystä. Hakapään esitystä täydentää liki 60-sivuinen liiteosasto, jonka selkeät tilastolliset esitykset jo sinällään antavat tiivistetyn kuvan suomalaisen kirjan yhteisön varhaisvaiheista ja kehityksestä.

Häggmanin etenemisen linja on toisentyyppinen. Hän on jakanut pitkän tarkastelujakson osaperiodeihin niin, että ensimmäisen jakson muodostavat vuodet 1857-1871, joiden aikana Suomen kustannusyhdistys elvyttää suomalaisen kirjallisen elämän. Toista periodia (18721905) luonnehtivat kirjatuotannon ja -välityksen massamarkkinat. Seuraavan jakson (1906-1939) läpäisevä ja hallitseva, myös kirja-alalle ulottuva teema on politiikka, kun puolestaan viimeisen, pisimmän ajanjakson tematiikkaa ovat kirja-alan teknologinen kehitys, talouden muutokset, globalisaatio, syvenevä kapitalistinen kilpailu ja siitä seurannut aggressiivinen yrityspolitiikka. Häggmanin jäsennystapa on tuttu, mutta tässäkin toimiva, hänen aikaisemmista kirjatuotannon tutkimuksistaan Piispankadulta Bulevardille. WSOY:n historia 1878-1939 (2001) ja Avarammille aloille, väljemmille vesille. WSOY: $n$ historia 1940 2003 (2003). Lineaariseen esitystapaan liittyvän monoliittisen tylsyyden vaarat Häggman välttää lomittamalla pientä ja suurta historiaa. Näin syntyy hallittua mosaiikkia, jossa kirjan yhteisö, kirjallisuusinstituutio tai -järjestelmä valottuu useasta näkökulmasta.

Kirjan tie lukijalle ja Paras tawara maailmassa muodostavat tietyistä eroistaan huolimatta kokonaisuuden, joka varsin kattavasti kuvaa suomalaisen kirja-alan kehityksen, muutokset, nousut ja laskut yli kahden sadan vuoden ajalta. Joistakin tutkijoiden yksittäisistä tulkinnoista voidaan tietysti olla eri mieltä. Monelle kirjallisuudentutkijalle kirjallisuushistorialliset jäsennykset, jotka historioitsijat ottavat jokseenkin annettuina, ovat problemaattisia. Sosiologisesti suuntautunut kirjallisuudentutkija puolestaan odottaisi tutkimuksilta täsmällisempää arvoanalyysia ja ideologiakritiikkiä sekä tulkintaa kuvattujen ja analysoitujen ilmiöiden merkityksistä kirjallisuuden sisältöihin. Kirjallisuussosiologi jää kaipaamaan kuvausten lisäksi tarkempaa analyysia sosiaalisten järjestelmien 
hierarkkisista kohtaamisista kirja-alan kontekstissa. Eikä häntä varmasti tyydytä se Jyrki Hakapään kategorinen toteamus, että käsitteenä kirjallisuusinstituutio olisi jotenkin kirjan yhteisöä jäykempi. Näin siksi, että kirjallisuusinstituution käsitekään ei ole mitenkään yksioikoisiin määritelmiin pysähtynyt käsite. Hakapään ja Häggmanin tutkimusten puolustukseksi todettakoon, ettei edellä esitetty problematiikka ole kuulunut niiden tutkimustehtäviin. Haasteen voi ajatella myös toisinpäin: Hakapään ja Häggmanin tutkimukset ovat tuottaneet tietoa ja avanneet asetelmia, joihin kirjallisuudentutkijoiden - niin sosiologisesti suuntautuneiden kuin kontekstuaalista tekstitutkimusta harjoittavien - tulisi innolla tarttua. Kaikkineen Hakapään ja Häggmanin kirjahistorialliset teokset ovat kirjallisuudentutkijalle vähintäänkin välttämätöntä yleissivistystä.

\section{Risto Turunen}

\section{Arkistot avautuvat kirjalli- suudentutkimukselle}

Elsi Hyttinen ja Katri Kivilaakso (toim.): Lukemattomat sivut: Kirjallisuuden arkistot käytössä. Helsinki: SKS, 2010. 231 s.

Kirjallisuudentutkimuksessa arkistojen hyödyntäminen on pitkään kuulunut etupäässä elämäkertojen kirjoittajien työnkuvaan. 1900-luvun jälkipuolen teoreettiset ja metodiset trendit ohjasivat tekstien lähilukuun ja karsastivat kaikkea, joka vähänkin vihjaisi tekstin tekijään, syntyprosessiin tai historialliseen kontekstiin. Viime aikoina kirjallisuudentutkijoiden kiinnostus arkistoja kohtaan on kuitenkin kasvanut. Esimerkiksi Helsingin yliopiston kotimaisen kirjallisuuden oppiaineessa on järjestetty arkistojen käyttöön opastavia kursseja ja Suomalaisen Kirjallisuuden Seuran kirjallisuusarkisto on lähestynyt kirjallisuudentutkijoita yhteisin seminaarein. Tuorein esimerkki arkistojen avautumisesta kirjallisuudentutkimukselle on Elsi Hyttisen ja Katri Kivilaakson toimittama artikkelikokoelma Lukemattomat sivut: Kirjallisuuden arkistot käytössä.

Kokoelma esittelee kahdeksan tutkijan voimin ja yhdeksän artikkelin verran arkistojen hyödyntämisen mahdollisuuksia kirjallisuudentutkimuksessa. Aiheiltaan ja kohteiltaan monipuolisissa artikkeleissa syvennytään muun muassa arkistoihin biografisen tiedon lähteinä, pohditaan muistelmakäsikirjoitusten lajityyppiä sekä tutkitaan teosten syntyprosessia käsikirjoitusten ja kirjeenvaihdon valossa. Vaikka Lukemattomia sivuja ei varsinaisesti ole tarkoitettu oppikirjaksi, se sopii hyvin opiskelijoiden luettavaksi esimerkkinä niistä menetelmistä ja käytänteistä, joilla arkistoja hyödynnetään kirjallisuudentutkimuksessa.

Jos Lukemattomien sivujen tarkoituksena on kannustaa opiskelijoita ja tutkijoita tutustumaan laajemmin arkistoihin, johdantoartikkelin tapa esitellä arkistoa foucault'laisen vallankäytön ilmentymänä hieman oudoksuttaa. Kun tutkijoita aiemmin karkotettiin arkistoista tylsillä tarinoilla pesulakuiteista, niin nyt hei- 
tä pelotellaan arkistovirkailijoilla, jotka valvovat asiakkaan jokaista liikettä kuin vartijat vankilassa. Arkiston käsitteen ja instituution selvittelyn sijasta olisi kenties kirjallisuudentutkijan kannalta kiinnostavampaa, jos johdannossa olisi paneuduttu enemmän arkistoaineiston käytön ja käyttämättömyyden historiaan, käytäntöihin ja haasteisiin.

Yksi käytännön ongelma arkistoaineistoa tutkivalle on se, miten viitata systemaattisesti ja tarkasti arkistolähteisiin, jotka usein ovat olemukseltaan epäjärjestelmällisiä. Ongelma näkyy valitettavasti myös Lukemattomien sivujen epäyhtenäisissä viittauskäytännöissä (epäyhtenäisyyttä on myös painetun kirjallisuuden osalta). Asia on tärkeä, koska esimerkiksi juuri Kirjallisuusarkistossa revisioidaan vanhentuneilla periaatteilla järjestettyjä aineistoja. Vaarana on, että aiemman tutkimuksen viittaushistoria menetetään kokonaan, mitä voisi verrata vaikkapa siihen, että painetuista kirjoista poistettaisiin sivunumerot.

Kokoelman parasta antia ovat artikkelit, jotka osoittavat, miten rikasta aineistoa arkistosta löytyy ja miten monipuolisesti sitä voidaan tarkastella. Perinteisintä arkistotutkimusta edustaa Hyttisen artikkeli, jossa hän jäljittää eri arkistoista biografisia merkintöjä unohdetusta työväenkirjailijasta Elvira Willmanista. Toisenlaista lähestymistapaa kirjailijaan edustaa Kaisa Kurikan artikkeli, jossa tarkastellaan Algot Untolan lukuisien tekijänimien kompleksista vyyhtiä arkistoaineiston valossa. Untolan tapaus mutkistuu vielä entisestään, kun sitä analysoidaan Gilles Deleuzen ja Michel Foucault'n käsittein. Älylliseltä silmänkääntötempulta vaikuttaakin se, että ensin korostetaan käsikirjoitusten materiaalisuutta ja ainutkertaisuutta, mutta heti sen jälkeen materiaalisuutta tulkitaan institutionaalisesti, jotta ainutkertaiset käsikirjoitukset voidaan rinnastaa painettuihin ja julkaistuihin teksteihin.

Julkaisemattoman ja julkaistun välinen problematiikka kulkee muutoinkin läpi koko artikkelikokoelman. Kivilaakson ja Anna Kuisminin artikkeleissa se kytkeytyy muistelmakäsikirjoitusten lajiin. Edellinen kokee ongelmaksi Elina Vaaran muistelmaluonnosten vaihtumisen lajityypistä toiseen, ja jälkimmäinen ihmettelee, miksi Anna-Maria Tallgrenin yksityiseksi tarkoitettu nuoruudenmuistelma on kirjoitettu kuin julkaistavaksi tarkoitettu teos. Minna Maijalan Minna Canthia ja Kukku Melkaksen Maila Talviota käsittelevissä artikkeleissa tarkastellaan käsikirjoitusten ja kirjeenvaihdon valossa mentorien ja kustannustoimittajien osuutta julkaistujen teosten syntyprosessiin. Kummassakin tulee ilmi, miten kirjailijoita on kehotettu lieventämään ilmaisuaan vastaanottajien moraalisen paheksunnan pelossa. Suvi Ratinen puolestaan vertaa Ain'Elisabet Pennasen julkaisemattoman romaanikäsikirjoituksen ja julkaistujen romaanien kotikuvausta. Käsikirjoitus osoittautuu poikkeukselliseksi siinä, että naisen ja kodin suhde kuvataan ensimmäistä kertaa negatiivisessa valossa.

Hanna Karhun artikkeli on sikäli merkittävä, että se on Suomessa ensim- 
mäinen, joka soveltaa 1970-luvun alussa syntynyttä ranskalaista geneettistä kritiikkiä (critique génétique). Geneettinen kritiikki on kirjallisuudentutkimuksen suuntaus, joka on kehitetty nimenomaan modernien käsikirjoitusten analyysiin ja tulkintaan. Karhun kohteena on Otto Mannisen käsikirjoitusluonnos, josta hän hahmottaa paitsi runon syntyprosessin eri kerrostumia myös intertekstuaalisia viittauksia.

Artikkelit tarjoavat runsaasti erinomaisia yksittäisiä huomioita, joilla on myös yleistä merkitystä kirjallisuudentutkimukselle. Ensinnäkin se, että kirjallisuushistoriat kirjoitetaan yleensä painettujen tekstien pohjalta, mikä on ongelma etenkin näytelmäkirjallisuuden kohdalla, jota ei aina paineta, vaikka sitä ahkerasti esitettäisiinkin. Toiseksi se, että painettuja tekstejä lukiessa on hyvä pitää mielessä, että etenkin teosten loput voivat usein olla painostuksen edessä muutettuja. Ja etenkin arkistojen käyttöjä aloittelevan tutkijan on hyvä tietää, että esimerkiksi tiettyä kirjailijaa koskeva aineisto ei useinkaan ole samassa arkistossa, vaan se voi olla hajallaan eri arkistoissa ja jopa muiden kuin kyseisen kirjailijan henkilöarkistojen yhteydessä.

Lukemattomat sivut onnistuu muuttamaan kuvan pölyttyneestä arkistolähtöisestä kirjallisuudentutkimuksesta osoittamalla, miten paljon kiinnostavaa ja vielä suurimmaksi osaksi tutkimatonta aineistoa arkistoista löytyy. Vaikka käsikirjoitusten ainutkertaisuus ja autenttisuus johtuukin nimenomaan niiden tuotantohistorian kytkeytymisestä tekijäänsä, ei vanhakantainen biografia tai tekijäkeskeisyys ole ainoa tapa hyödyntää arkistoja. Artikkelit osoittavat, että arkistoaineistolla on hyvien kysymyksenasetteluiden valossa potentiaalia kyseenalaistaa useita kirjallisuudentutkimuksen peruskäsitteitä ja käsityksiä. Yhtenä keskeisimmistä sen, minkä ymmärrämme kirjallisuudentutkimuksen kohteeksi.

\section{Veijo Pulkkinen}

\section{Kirjantekemisen konkretiaa keskiajalla}

Tuomas Heikkilä: Piirtoja ja kirjaimia. Kirjoittamisen kulttuurihistoriaa keskiajalla. Helsinki: SKS, 2009. 191 s.

Tuomas Heikkilä tarkastelee teoksessaan keskiaikaista kirjaa esineenä, kirjoittamista fyysisenä tapahtumana, kirjoitustyylejä sekä kirjan kopioimista, levittämistä ja säilyttämistä kirjastoissa. Samoin mukana ovat keskeiset toimijat, kuten kopistit, kuvittajat, kirjakauppiaat ja notaarit. Heikkilä käsittelee siis kirjoittamisen ja kirjantekemisen luonnetta ja edellytyksiä keskiajalla kaikessa niiden konkreettisuudessa. Teoksen lopussa on katsaus aikaan, jolloin kirjapainotaito teki tuloaan ja ryhtyi kilpailemaan käsikirjoitusten kopioinnin kanssa. Heikkilä on kirjoittanut esityksensä yleiseurooppalaisesta perspektiivistä mutta paljolti Suomen oloja ja 
Suomessa säilynyttä materiaalia silmällä pitäen. Hän painottaa Suomessa säilyneen materiaalin kansainvälisyyttä ja eurooppalaisuutta. Esityksen painopiste on uskonnollisissa teksteissä ja asiakirjoissa, kaunokirjallisuutta edustaa lähinnä epiikka. Kaunokirjallisuuteen liittyvää aineistoa Heikkilä olisi voinut käsitellä mielestäni enemmänkin.

Heikkilän esityksestä on kiehtovaa lukea, miten monenlaista inhimillistä kekseliäisyyttä oli olemassa ennen kirjapainotaidon keksimistä. Tämä kekseliäisyys ilmenee esimerkiksi materiaaleissa ja kirjoituksen apuneuvoissa ja niiden valmistuksessa, olipa kysymyksessä pergamentti, paperi, vesileima, muste tai sulkakynä. Piirtoja ja kirjaimia osoittaa havainnollisesti, millaisia johtopäätöksiä tutkija voi vanhojen fragmentaaristen tekstien materiaalin, vesileimojen, kirjoitusasun ynnä muiden samankaltaisten asioiden perusteella tehdä.

Toinen keskeinen seikka, joka Heikkilän esityksestä käy ilmeiseksi, on se, että monet niistä kirjoittamiseen ja kirjalliseen tekstiin liittyvistä ratkaisuista, jotka ovat edelleenkin käytössä, ovat peräisin keskiajalta pikemminkin kuin antiikista. Tästä kertovat esimerkiksi kirjainmuodot, tyhjä tila sanojen välissä ja välimerkkien käyttö.

Kirjoitustyyleistä annetaan havainnollisia esimerkkejä. Kaarle Suuren aikana kehittynyt karolinginen minuskeli lukemista helpottavana kirjoitustyylinä saa erityistä huomiota osakseen. Siihen nähden olisi ollut kiinnostavaa muistaa Einhardin (Vita Karoli Magni) tieto Kaar- len omista vaikeuksista kirjoitustaidon suhteen. Kaarlella oli Einhardin mukaan tapana pitää vuoteessa tyynyjen alla kirjoitustauluja (tabulas) ja vihkoja (codicellos), "mutta liian myöhään aloitettu työ ei erityisemmin luistanut".

Keskiaikaisen kirjoituksen muodoista riimukirjoitus mainitaan ohimennen Brittein saarten yhteydessä. Siitä olisi ollut kiinnostavaa kuulla enemmänkin, kun ottaa huomioon pohjoismaiset riimukirjoitustekstit.

Kirjastojen ja kirjakokoelmien määristä annetaan kiinnostavaa tietoa. Englantilaisen piispa Richard Buryläisen, Danten nuoremman aikalaisen, kirjastossa lienee ollut 1500 käsikirjoitusta eli enemmän kuin koko Suomessa keskiajalla. Unkarin kuninkaan Matthias Corvinuksen kirjasto 1400-luvun jälkipuoliskolla käsitti noin 2000 käsikirjoitusnidettä; sellaisenaan se oli läntisen kristikunnan suurin Vatikaanin kirjaston jälkeen. Määrät ovat peräti vähäisiä verrattuna Córdoban kalifin kirjastoon. Heikkilä mainitsee niteiden määräksi 400 000; määrä saattaa olla liioiteltu, mutta joka tapauksessa kyseessä on huomattavan suuri määrä kristikunnan kirjastoihin verrattuna. Kirjojen hankkimiseksi yksittäiset oppineet kävivät "usein hämmästyttävän laajaa kirjeenvaihtoa", kuten Heikkilä toteaa. Luostarit olivat myös kehittäneet omat verkostonsa käsikirjoitusten kopioimista, vaihtamista, myymistä ja ostamista varten.

Heikkilän elegantti, hienosti kuvitettu kirja osoittaa myös ne huomattavat kauneusarvot ja pyrkimyksen taiteelliseen 
havainnollisuuteen, jotka keskiaikaisissa käsikirjoituksissa tulevat esille. Riittää kun mainitsee kuvat Troijan palosta tai takan ääressä lämmittelevästä lukijasta. Myös vähemmän kauniista sivuista annetaan esimerkkejä.

Vaikka työskentelyolosuhteet olivat usein ankeita kylmyydestä ja heikosta valaistuksesta johtuen, ergonomiaakin pyrittiin kehittämään: esimerkiksi Jean Miélot'n kirjoituskammiosta ei puuttunut vuodettakaan, kuten säilyneestä kuvasta ilmenee (51). Eräästä näkökohdasta olisi toivonut hieman enemmän tietoa. Heikkilä toteaa valaistusolosuhteiden hankaluuden ja turvautumisen kynttilöihin ja päreisiin. Samoin hän muistuttaa siitä, että joistain keskiaikaisista käsikirjoituksissa voidaan erottaa, mitkä osuudet on kirjoitettu kesällä, mitkä talvella. Miélot'n kohdalla hän toteaa, että tällä oli käytettävissään suurennuslasi - huomattava harvinaisuus tuolloin. Mutta entä silmälasit? Muun muassa optiikan kehityksen ansiosta myöhäiskeskiajalla tuli mahdolliseksi myös silmälasien käyttö. Voisi hyvinkin ajatella, että renessanssihumanistien työ, käsikirjoitusten yksityiskohtainen tutkimus, ei olisi ollut mahdollista ilman tällaista apuvälinettä.

Eläinten ystävät eivät ehkä viehäty kuvasta, jossa käyskentelee kolme lehmää ja jonka tekstinä on: "Muutamastakin lehmästä saa sivukaupalla hyvää pergamenttia" tai toteamuksesta: "ahkera kirjoittaja kulutti hanhittain sulkakyniä", niin paikkansa pitäviä kuin väitteet varmasti ovatkin. Jonkinlaisia kauneusvirheitä ovat myös eräät toistot ja kovin kuluneen sanonnan "ajan hammas" käyttö. Heikkilän käyttämien kansankielisten tekijänimien kohdalla olisi joissain kohden ollut aiheellista muistuttaa myös usein käytetyistä latinankielisistä nimistä (esimerkiksi Jacopo da Varazze, Legenda aurean tekijä, tunnetaan useimmiten nimellä Jacobus de Voragine).

Kirjaan liittyy käyttökelpoinen terminologinen sanasto. Lähde- ja kirjallisuusluettelon ohella mukana on myös suppea mutta hyödyllinen Lisälukemistoa-osasto; mielellään siinä olisi nähnyt myös E. R. Curtiuksen klassisen teoksen Europäische Literatur und lateinisches Mittelalter, jossa tuodaan esille kirjaan liittyvää topiikkaa, sekä Päivi Mehtosen teoksen Poetria nova, jossa on runousopin ohella myös yleensä keskiaikaisen kirjalliseen kulttuuriin liittyvää materiaalia.

\section{H. K. Riikonen}

